\title{
DỨBin
}

Technological University Dublin ARROW@TU Dublin

\section{Philanthropy-Supported Journalism}

\author{
Harry Browne \\ Technolgical University Dublin, harry.browne@tudublin.ie
}

Follow this and additional works at: https://arrow.tudublin.ie/aaschmedart

Part of the Journalism Studies Commons, and the Social Influence and Political Communication Commons

\section{Recommended Citation}

Brown, H. (2019). Philanthropy-Supported Journalism. The International Encyclopedia of Journalism Studies, first published 29th April. doi:10.1002/9781118841570.iejs0069

This Article is brought to you for free and open access by the School of Media at ARROW@TU Dublin. It has been accepted for inclusion in Articles by an authorized administrator of ARROW@TU Dublin. For more information, please contact arrow.admin@tudublin.ie, aisling.coyne@tudublin.ie, gerard.connolly@tudublin.ie.

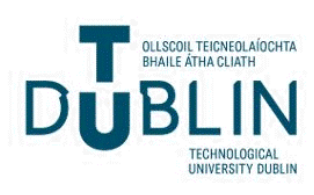




\title{
Philanthropy-Supported Journalism
}

Harry Browne

Dublin Institute of Technology

harry.browne@dit.ie

\section{Word Count: 2000 words}

\begin{abstract}
There is a widespread perception that the market is failing to ensure the provision of high quality, impactful journalism, especially investigative work and in-depth coverage of governmental and international affairs. One answer to that market failing has been the development of philanthropy-supported journalism. Some writers see this as a potentially important, if partial, solution to journalism's problems, strengthening the editorial focus on creating social and policy impacts. Others have expressed concern that philanthropic support draws journalists toward elite orientations, with both funders themselves and their desired audiences representing the socio-economic upper tiers.
\end{abstract}

Keywords: business models; investigative journalism; journalism sociology; philanthropy; impact

\section{Main Text}

While there is a long history of journalism produced by nonprofit organisations and sustained to a greater or lesser degree by donor funding, it was in the wake of the global financial crisis of 2008 that significant philanthropic support for news organisations grew in scale, in interest to researchers, and in apparent acceptability to the profession. In 2008 in the United States, for example, some $\$ 20$ million was donated to news nonprofits (McChesney \& Nichols, 2011, p. 88), but between 2009 and 2011 approximately \$1.86 billion was given by US foundations in what are described as media-related grants, with researchers classifying some $\$ 527$ millions of that as directed at "journalism, news and information" (Henry-Sanchez \& Koob, 2013, p. 12). An online mapping tool developed by a network of foundation funders seeking media impact showed, in late 2017, a global total of \$9 billion in foundation media grants since 2009 (Media Impact Funders, n.d.). Grants of \$1 million or more were paid during that period by one funder, the Bill and Melinda Gates Foundation, to public and commercial news organizations to support reporting on international development issues: recipients included ABC News, AllAfrica.com, Al Jazeera, El País, the Guardian, National Public Radio, PBS Newshour, and Public Radio International (Scott, Bunce, \& Wright, 2017, p. 164). The Knight Foundation, founded by a US local newspaper family business, extended its funding beyond nonprofit recipients to commercial organizations beginning in 2010: one notable donation was \$2.6 million to Guardian News \& Media to develop "innovation" in mobile delivery. While nonprofit news organisations rely 
on philanthropy for funding to a far greater degree than commercial ones do, the distinction can be somewhat blurred by the tendency of the nonprofits to partner with larger outlets to distribute their work. The foundation-funded ProPublica, for example, launched its first investigation in 2008 in partnership with the popular CBS television programme Sixty Minutes, and has continued to employ such relationships with organizations such as the New York Times to increase its reach (Benson, 2017; Browne, 2010). Thus even when funders are directly supporting a nonprofit such as ProPublica, they are also offering indirect subsidies to the commercial organizations that use its journalistic work. Journalism nonprofits have largely framed their work in "Fourth Estate" and "watchdog" terms similar to those employed at the quality end of the commercial market, and the distinction between commercial and nonprofit organizations may on occasion be somewhat confusing: in 2013 Amazon billionaire Jeff Bezos bought an existing commercial newspaper company, the Washington Post, to preserve and develop its journalism; in the same year, eBay billionaire Pierre Omidyar established First Look Media as a nonprofit, and through that structure has funded an important investigative-journalism website, The Intercept. Omidyar's intervention is philanthropy, whereas that of Bezos is an investment, but the intent and effect are arguably similar.

Whether directed into nonprofit, public-service or commercial organizations, philanthropic funding has mostly, though not exclusively, been used to support journalistic work in areas and genres that are regarded, in the 21st-century media environment, as difficult to support through purely market-based mechanisms of advertising and audience payments. These include investigative reporting, stories from the workings of government and international affairs. Although foundation-supported journalism is at least somewhat protected from the market, it is however subject to other metrics familiar from the donor realm, notably - as Benson (2017) has noted - the requirements of "impact" and "sustainability". The latter suggests that the organizations receiving support should eventually be in a position to support themselves financially; while "impact" suggests that work should be measured by, for example, having discernable effects on public policy.

Although concern for this sort of social and public-policy impact is not unknown in traditional conceptions of journalism and its value, "impact" in commercial journalism has been more likely to be measured in audience numbers, or to a lesser extent in attractiveness to advertisers. A version of impact that is defined by the societal consequences of publishing particular works of journalism might even be seen to run counter to a traditional norm that directs journalists to disseminate "facts" without excessive concern for, or fear of, the consequences. It would be inaccurate to regard concern for social impact as a true novelty brought on by philanthropic priorities journalists in many societies have long boasted about, and won prizes for, stories that have achieved or contributed to results ranging from reforms to prosecutions. Nonetheless, the dedicated "Impact" sections on many nonprofit journalism websites, and the efforts by 
professionals and funders alike to develop a taxonomy of impact, indicate an increased salience for this concept of impact, under apparent donor influence.

Writing about and research into philanthropy-supported journalism, most of it in professional publications and philanthropy-sector reports, has for the most part treated such funding as good for society and journalism alike, constituting a timely intervention in a field of practice that faced an oft-cited "crisis" precipitated by various economic and technological factors. In this perspective, the main concern - especially for writers addressing the issue in the early period of the global financial crisis - was the likely inadequacy of philanthropic support in proportion to the need that confronts journalism. Westphal (2009), citing the example of the Kaiser Family Foundation's support for a medical-journalism initiative, briefly addressed the concerns of readers - "For health-news consumers, there's the question of whether the coverage is somehow shaped by the interests of the funder" - and of the foundation itself - "the loss-of-control issue when a firewall is established between funder and news organization" (2009, p. 7). More fundamental questions about the ethics and politics of philanthropic support for journalism have been unusual, though Edmonds (2002) cautioned in a relatively early analysis that "the benevolent fog that surrounds most foundations" tended to obscure the possibility "that they may have more of an agenda, not less, than a sponsoring corporation". Feldman (2007) argued, from his own experience, that left-leaning media organizations in the US had been effectively tamed by philanthropic donors applying both pressure and more subtle direction.

Scholarly efforts to measure the effects of philanthropic support on the practice of journalism have been slow to emerge and their findings have been somewhat inconclusive. Bunce (2016) examined the possible effects of the Bill and Melinda Gates Foundation's support for journalism addressing issues of international development, when that foundation itself has what is regarded in some development circles as a controversial role in relation to those same issues. Another study used content analysis and ethnographic methods to research how journalism at the humanitarian news agency IRIN endured the agency's shift from UN to philanthropic funding; the authors found no change in the agency's output to be more supportive of both capitalist markets and philanthro-capitalism, and pointed to "the over-riding significance of historically formed, individual values and dispositions and national and transnational level journalistic field logics, in mediating all forms of donor power" (Scott et al., 2017, p. 181).

A wide-ranging analysis by Benson (2017), however, has drawn more negative conclusions about foundation support for journalism nonprofits and its capacity to reform an American media system in crisis. He argued that donors' interest in building economic "sustainability" into the outlets they support meant, effectively, that such media would have to attract welleducated and high-earning audiences who could either directly support them through donations or be sufficiently attractive to political or luxury-brand advertisers hoping to reach them. Employing a study of who sits on the boards of US journalism nonprofits and 
the foundations that support them - a group of people only slightly less elite in their status and origins than those who run commercial media companies - Benson concluded that the foundations offering philanthropic support for journalism provided, in sociological terms, reinforcement for the elite pole of the journalistic field. Especially in the light of continuing concerns about the quality of news, fake and otherwise, consumed by the majority of populations in various countries, and the consequences for the nature and tone of those people's political participation, Benson suggested that this elite orientation constitutes a serious issue. He writes: "Although nonprofit journalistic organizations have made some notable civic contributions, they fall short of offering a strong critical alternative to the market failure and professional shortcomings of commercial journalism" (Benson, 2017, p. 2).

Applying insights from sociological literature that critiques the role of philanthropic foundations as bulwarks of the established order, Browne (2010) has argued that such shortcomings - elite orientation and the incapacity to offer a critical alternative to commercial journalism - are not failings of the philanthropic model for supporting journalism so much as they are its predictable features. Acknowledging that journalism "has never been pure and cannot afford to be choosy" (2010, p. 891), he challenges the idea of a unitary, passively constructed public interest in the rhetoric of both philanthropy and the High Modernist conception of journalism that it tends to support and sustain.

The normalisation of donor-supported journalism - funded by big philanthropic donors and also by small ones in its audience - has nonetheless continued apace, fuelled by what many of those donors perceive to be a democratic crisis with media at, or near, its centre. (It is interesting to note, given this focus on philanthropy "saving" traditional journalism, that there has been no sustained research focus on philanthropic support for the hyperpartisan media that is often blamed, at least in part, for the contemporary crisis.) Some scholars maintain that the positioning of journalism as a social good that should not only inform the public but also achieve impact - a positioning that flows from and through much of the philanthropic and research literature - offers a potentially positive new conception of both journalism and democracy. Studying the work and statements of the donor-supported International Consortium of Investigative Journalists, Konieczna and Powers (2016, p. 14) argue that the journalistic profession had "reacted to the changes of the twenty-first century by becoming unmoored from its democratic mission", but that philanthropy-driven concerns could restore that mission: in particular, an open acknowledgment of the importance of impact in journalism would be beneficial insofar as it would lead to improvement in both transparency and outcomes.

SEE ALSO: IEJS0028, IEJS0043, IEJS0049, IEJS0067, IEJS0093, IEJS0134

\section{References}

Benson, R. (2017). Can foundations solve the journalism crisis? Journalism, 
1464884917724612.

Browne, H. (2010). Foundation-Funded Journalism: Reasons to be wary of charitable support. Journalism Studies, 11(6), 889-903.

Bunce, M. (2016). Foundations, philanthropy and international journalism. Ethical Space: The International Journal of Communication Ethics, 13(2/3), 6-15.

Edmonds, R. (2002). Getting Behind the Media: What are the subtle trade-offs for foundation-funded journalism? Philanthropy (March/April).

Feldman, B. (2007). Report from the Field: left media and left think tanks_foundationmanaged protest? Critical Sociology, 33(3), 427-446.

Henry-Sanchez, B., \& Koob, A. (2013). Growth in Foundation Support for Media in the United States. Foundation Center. Retrieved from http://foundationcenter.org/gainknowledge/research/pdf/mediafunding_report_2013.pdf

Konieczna, M., \& Powers, E. (2016). What can Nonprofit Journalists Actually do for Democracy? Journalism Studies 18(12): 1542-1558.

McChesney, R., \& Nichols, J. (2011). The Death and Life of American Journalism: The Media Revolution That Will Begin the World Again. New York: Nation Books.

Media Impact Funders. (n.d.). Media Impact Funders: A knowledge network for media funders. Retrieved September 11, 2017, from http://mediaimpactfunders.org/

Scott, M., Bunce, M., \& Wright, K. (2017). Donor power and the news: The influence of foundation funding on international public service journalism. The International Journal of Press/Politics, 22(2), 163-184.Westphal, D. (2009). Philanthropic foundations:

Growing funders of the news. Los Angeles: Annenberg School for Communication, University of Southern California. Retrieved from https://communicationleadership.usc.edu/files/2015/07/PhilanthropicFoundations.pdf

\section{Further Reading}

Fandos, N. (2016, December 7). Nonprofit Journalism Groups Are Gearing Up With Flood of Donations. The New York Times. Retrieved from 
https://www.nytimes.com/2016/12/07/business/media/nonprofit-journalism-groups-aregearing-up-with-flood-of-donations.html

Konieczna M (2018) Journalism without Profit: Making News When the Market Fails. Oxford: Oxford University Press.

Schriffyen, A (2016) A marriage of convenience - Looking at the new donor-journalism relationship. Center for International Media Assistance, 3 October. Available at: http://www.cima. ned.org/blog/new-donor-journalism-relationship/

Tofel, R. J. (2013). Non-Profit Journalism: Issues Around Impact. ProPublica. Retrieved from https://s3.amazonaws.com/propublica/assets/about/LFA_ProPublica-whitepaper_2.1.pdf?_ga=2.103211456.1100310922.1505115846-50670184.1505115846

\section{Brief author biography}

Harry Browne is senior lecturer in the School of Media at Dublin Institute of Technology, and co-ordinator of the Centre for Critical Media Literacy there. His books include Public Sphere (Cork University Press, 2018) and The Frontman: Bono (In the Name of Power) (Verso, 2013). His journalistic work has been published widely and appears in the anthology Great Irish Reportage (Penguin Ireland, 2013). 